\title{
Transition to company-based vocational training in Germany by young people from a migrant background - the influence of region of origin and generation status
}

\author{
Ursula Beicht $^{*}$, Günter Walden ${ }^{1}$ \\ ${ }^{1}$ Federal Institute for Vocational Education and Training, 53175 Bonn, Germany
}

Received: 01.12.2018; Accepted: 04.01.2019; Published: 30.04.2019

\begin{abstract}
Context: For young people with a migrant background in Germany transition from school to company-based vocational training is much more difficult than for non-migrants. This remains true, when data is controlled for the lower performance of young migrants in general education. In this paper we investigate if and how far the chances of transition to companybased vocational training and the acquisition of different school leaving certificates depend from the migration generation and the region of origin of young migrants. The question is, if disadvantages of young migrants diminish with a longer stay of their family in Germany and if this is also the case for the different groups of regions of origin (Southern Europe, East Europe, Turkey, other Middle East and North Africa, Other regions).
\end{abstract}

Approach: We conduct multivariate analyses on the basis of data from the German Educational Panel Study (NEPS). Our analyses relate to young people who left a general education school after Year 9 in the summer of 2011 or Year 10 in the summer of 2012. Our database comprises information provided by a total of 5,952 school leavers.

Findings: For all four origin groups worse chances in comparison to non-migrants were detected. But there are differences in the disadvantages of opportunity between the various groups. They acquire more often lower school qualifications than their counterparts not from a migrant background and also have worse chances than the latter of successfully pro-

*Corresponding author: beicht@bibb.de 
gressing to company-based vocational education and training. This applies even if other important influencing factors such as social origin are taken into account. Young people from a Turkish or Arab background have the lowest chances in general education and vocational training. As generation status rises disadvantages diminish for all origin groups, but with different magnitudes. A clear upwards-directed integration can be observed solely for the East European origin group.

Conclusion: The results of our analyses signalise a clear need for action on the part of German policy makers and German society to reduce the educational disadvantages suffered by young migrants and to develop an effective support mechanism. Integration is rarely achieved in the short term. It is a long-term task which frequently extends over several generations.

Keywords: Access to education and training, ethnicity, migrants, educationally disadvantaged, transition from secondary to further education and training, school leavers, quantitative research, vocational education and training, VET

\section{Introduction}

Migrants and their descendants represent growing proportions of the population in many Western countries. The greatest possible educational success is of crucial significance to the integration of migrants into highly developed Western societies. When comparing the educational success of migrants and their descendants with that of the indigenous population, numerous investigations looking at various countries have arrived at the conclusion that the outcomes achieved by persons from a migrant background are poorer in average terms. Examples of countries for which such studies have been conducted include France, Switzerland, the Netherlands and Germany (e.g. Azzolini \& Barone, 2013; Heath, Rothon, \& Kilpi, 2008; Jackson, Jonsson, \& Rudolphi, 2012; Phalet, Deboosere, \& Bastiaenssen, 2007). Nevertheless, such a finding does not apply consistently to all Western host countries that have formed an object of consideration in this regard. In the USA, children of migrants often enjoy advantages over children with no migrant background in the school system (e.g. Chiswick \& Deb-Burman, 2003; Ryabov, 2009). A similar circumstance pertains in Canada (Picot \& Hou, 2011).

If we look at the countries of origin of migrants, major differences in educational success can be identified between individual origin groups (e.g. Algan, Dustmann, Glitz, \& Manning, 2009; Domingues Dos Santos \& Wolff, 2011; Dustmann, Frattini, \& Lanzara, 2012). Alongside country of origin, relevant studies also often identify the generation status of migrants as an important influencing factor for educational success. The tendency is for disadvantages 
in the educational system to fall off in the second immigration generation as opposed to the first (Algan et al., 2009; Azzolini \& Barone, 2013).

If we consider besides the general education system vocational education and training, migrants are also often at a disadvantage compared to the population with no migrant background (Tjaden, 2013).The dominant role within the German VET system is played by dual training, where the learning venues are the company and the vocational school. This is the most significant vocational education and training sector in the country, and the awarding of training places is usually decided by the companies. For this reason, the system is frequently referred to as "company-based training". More than half of all young people pass through this training system. To this extent, it plays a prominent part in the integration of young migrants into German society.

In Germany, no formal minimum requirements regarding the level of school qualification to be achieved are stipulated for entry to company-based training. For this reason, young people aspiring to enter dual training hold very different types of school leaving qualifications. These range from no certificate at all to a higher education entrance qualification. However, most of those interested in pursuing training hold a school leaving certificate at lower secondary level. A distinction in this regard needs to be drawn between the basic lower secondary, the qualifying lower secondary and the intermediate secondary school leaving certificate, which represents a further and higher level compared to the two other versions of the lower secondary school leaving certificate. The chances of making a successful transition to company-based vocational education and training depend significantly on the level of school qualification achieved. The transition from school to vocational education and training does not always run smoothly, particularly for young people with lower levels of prior school learning.

Many existing studies show that young migrants in Germany have significantly more difficulties than young people not from a migrant background in entering vocational training upon completion of general schooling (for a summary, see Beicht \& Walden, 2017b). The school qualifications of migrants are an important reason for this. Germany is one of the countries in which young people from a migrant background achieve significantly worse average outcomes in general schooling than the non-migrants. This is borne out by several investigations (Kristen et al., 2011; OECD, 2018b). The aim of the present paper is to expand the status of research relating to the transition from school to VET by young people from a migrant background in Germany. We address the issue of the significance that can be accorded to the influencing factors of "region of origin" and "generation status" with regard to successful transition to company-based training. These are aspects that have been identified as important in international comparative terms.

In 2015, as many as $29 \%$ of young people in Germany aged between 15 and 20 were from a migrant background. Young migrants in Germany represent a highly heterogeneous group. 
Particularly high proportions of this body of persons are formed by descendants of so-called "guest workers" originally recruited from southern Europe and Turkey and by young people from "late resettler" families (immigrants of German descent from the successor states of the former Soviet Union and other eastern European countries). In addition to this, increasing numbers of persons of Arab or African origin have been arriving in Germany over recent years. Because immigration began over 50 years ago, young people who immigrated themselves find themselves alongside second or third generation descendants of immigrants in the educational system as they attempt to make the transition from school to VET or to the world of work. A large majority of young migrants has already got German citizenship.

We will begin below by looking at existing research results relating to the significance of region of origin and generation status for educational success and transition to companybased training before moving on to specify the issue at hand and formulate hypotheses. The fundamental data and the methodological approach adopted will then be explained, and the results will be presented. The paper ends with a summary and conclusions.

\section{State of research}

\subsection{Reasons for differences in educational success between the non-mi- grants and migrants and between various origin groups}

The introduction has already indicated that young people with a migrant background are more likely than non-migrants to exhibit poor educational outcomes. At the same time, there are also substantial differences between individual origin groups. In Germany, lower average levels of educational success are recorded for all origin groups when compared to non-migrants (Algan et al., 2009), but average performance by migrants from a Turkish background is worse than that of other origin groups (Algan et al., 2009). But young people of eastern European origin are most likely to progress to VET. Youngsters from a Turkish or Arab background are the group least likely to achieve this progression (Beicht \& Walden, 2014).

Why are there such major differences between individual origin groups amongst migrants? At first reasons for differences in educational success between migrants and non-migrants and between various origin groups could be connected with the characteristics of particular individuals and groups. One explanation has its basis in the social position which migrants (or their ancestors) occupied in their respective countries of origin. Individual origin groups may differ with regard to the structure of original social positions. Existing investigations show a positive correlation between the social position of migrants in the country of origin and the educational success achieved in the host country (Feliciano, 2005, 2006; Ichou, 2014).

Chiswick indicates that unequal levels of educational success may possibly be explained by different educational preferences of various groups that have come about for cultural, reli- 
gious and historical reasons, and by the fact that migrants often have a lower average socioeconomic status and are thus over-represented in disadvantaged groups of persons (Chiswick 1988, cited here from Domingues Dos Santos \& Wolff, 2011). Many investigations show that migrants frequently achieve lower incomes or a lesser social status than persons not from a migrant background (e.g. Chiswick \& Miller, 2009). Social origin continues to exert a formidable influence on educational success in Germany, and migrants are more likely to come from parental homes which have a lower social status. The higher the social class, the better educational success is likely to be in general terms (e.g. Ditton, 2008). With regard to the transition to company-based training in Germany, the main influence of social origin is revealed in the general school qualification achieved (e.g. Beicht \& Walden, 2015a).

The classical distinction between primary and secondary effects of origin drawn by Boudon (1974) lends itself to a consideration of individual or group-related factors to explain the lower educational chances of migrants. Primary effects of origin designate the impacts of the parental home on educational success of children. Secondary effects of origin are considered to be variances in educational decisions made by different origin groups where the educational status of the children is equal.

Primary effects of a migrant background initially relate above all to mastery of the language of the host country (Heath et al., 2008). Primary effects are mainly reflected in the educational success of migrants in general schooling. Educational qualifications obtained at school may have a major influence on the chances of making the transition to vocational education and training. At the transition to company-based training, primary effects of origin represent the different resources available to applicants for a training place. The resources that young people from a migrant background have at their disposal are worse in overall terms. This circumstance, and their lower school qualifications in particular, play a considerable role in explaining differences vis-à-vis non-migrants (e.g. Beicht \& Walden, 2014; Hunkler, 2014). However, even if for school qualification and further resources possessed by the young people are controlled, the indication is still that migrants have lower chances of making the transition to company-based training (Beicht \& Walden, 2014; Eberhard, 2012).

It is likely that secondary effects of origin are also significant to the different chances of migrants and non-migrants at the transition to vocational education and training. Secondary effects of origin relate to differences in educational decisions and occupational preferences between young people whose school qualifications are the same. Numerous investigations conducted have indicated that migrants in Germany display a slightly lower level of interest in company-based vocational education and training than non-migrants (Beicht \& Walden, 2017a). It is possibly the case that migrant families are unable to assess the value of a dual training qualification correctly because they are usually unlikely to be familiar with such a training system in their countries of origin. Although migrants generally have high educational aspirations (e.g. Ichou \& Vallet, 2013; Jackson et al., 2012), in Germany these tend to 
relate to general educational qualifications and courses of higher education study rather than being directed towards vocational education and training (Becker, 2011).

There are probably also differences in the occupational preferences of migrants and nonmigrants. Existing studies show that migrants are significantly more likely than non-migrants to aspire to service occupations with higher social prestige but in which the prospects of obtaining a training place in Germany are generally lower than in manufacturing occupations (Beicht \& Walden, 2015b). Nevertheless, there is also evidence that chances of progression to company-based training for migrants are also lower if the varying occupational preferences are taken into account (Beicht \& Walden, 2015b).

Alongside the individual or group-related factors stated, reasons which need to be sought in external conditions may also play a role in terms of the differences in educational success. One particular aspect to be addressed in this regard is possible discrimination in the host country. The probability of this may, however, also be different for individual origin groups (e.g. Chiswick, 1988). With regard to the transition to company-based training, the specific focus is on the recruitment behaviour of companies, which are autonomous in respect of their decisions on selection of trainees. In this case, a distinction needs to be drawn between statistical discrimination (Spence, 1973; Thurow, 1979) on the basis of the signal effect created by the lower level of prior learning of migrants seeking to enter training and other forms of discrimination. It is also possible, for example, that existing xenophobic and racist attitudes within the population exert an impact on the recruitment behaviour of companies. Basing their work on the critical race theory approach developed in the USA, Chadderton and Wischmann (2014) emphasis the significance of racism, including for school and apprentice training in Germany and England.

\subsection{Reasons for differences in educational success by generation status of the migrants}

To which extent is educational success affected by the circumstance of whether persons are immigrants themselves as opposed to a situation where they or their parents were actually born in the host country? Studies from many countries show that educational success for migrants often increases in line with rising generation status (e.g. Dustmann et al., 2012; OECD, 2018a). The expectation that integration will become closer as a longer period of time is spent in the host country is in accordance with so-called classical assimilation theories, such as those formulated by Glazer and Moynihan (1963) and Gordon (1964). As Brown and Bean (2006) explain, classical assimilation theories assume that the process of adaptation to the host society will increasingly progress over the course of time as convergence to the norms and modes of behaviour in the host country takes place. Particular consideration in this regard is accorded to mastery of the language of the host country (e.g. Esser, 2006). Alba and Nee (2003) emphasize the role of institutions in their "new assimilation theory“. 
In some works relating to the assimilation theory doubt is cast on classical assimilation theory pursuing the idea of segmented assimilation (e.g. Portes \& Zhou, 1993). The latter theory states that there may be three different longer-term development routes for immigrants in the host country. One possible pathway continues to be adaptation to the new society within the meaning of classical assimilation theories. A second possibility is viewed as being socialisation to the lower strata or sub-milieus of the host country. The outcome in this case is a perpetuation of economic decline (Portes \& Zhou, 1993). The third route of development in the host country is the achievement of economic success whilst continuing to retain a separate cultural identity and to experience clear segregation from other population groups in the host society (Portes \& Zhou, 1993). Portes and Zhou give examples for the USA for all the assimilation pathways stated.

Investigations conducted in Germany show that most origin groups continue along an upwards route if comparisons are made of educational success in general schooling across various migration generations (e.g. Diehl \& Granato, 2018). There are, however, indications of patterns of downwards assimilation for young people from a Turkish background (Segeritz, Walter, \& Stanat, 2010). An available study on the influence of generation status on the chances of progression to company-based training for migrants comes to the conclusion that a higher generation status improves opportunities for such progression (Beicht \& Walden, 2017a). This investigation does not, however, differentiate migrants according to various countries of origin.

\section{Questions and hypotheses}

With regard to the transition to company-based training, we investigate the extent to which the chances of progression for young people from a migrant background are determined by their region of origin and generation status. We investigate a group of young people who left the general school system after Year 9 or after Year 10, usually having achieved a basic lower secondary, a qualifying lower secondary or an intermediate secondary school leaving certificate. The first question investigated is the extent to which acquisition of a general school leaving qualification - the central factor influencing transition to company-based training - depends on migrant background, various regions of origin and migration generation. We then move on to look at the main issue addressed by the present paper. This is the extent to which influences of a migrant background, migrants' region of origin and migration generations on progression to company-based training can be identified. Hypothesis 1a: Young people from a migrant background are likely to display lower levels of success in the school system than young people not from a migrant background even if we control for other cause variables. 
We adopt the following assumptions with regard to acquisition of a general school leaving qualification.

- Hypothesis 1b: The chances of acquiring higher school qualifications for the group of migrants as a whole should improve in accordance with the principle of upwards assimilation if the family of the young person has spent a longer time in Germany or as the number of migration generations increases.

- Hypothesis 1c: With regard to regional origin, results from other investigations lead us to expect that results will be poorer for young people from the Turkish or Arab region in particular. By way of contrast, results for the other origin groups should not differ significantly.

- Hypothesis 1d: School educational opportunities should improve in all origin groups of migrants as generation status rises.

We make the following assumptions with regard to the transition to company-based vocational education and training.

- Hypothesis 2a: Even if school leaving qualifications and further relevant influencing factors are taken into account, it is likely that lower chances of making the transition to company-based training will be revealed for young people from a migrant background as compared to young people not from a migrant background.

- Hypothesis 2b: We once again assume that classical assimilation theory will be the most probable route of development for migrants in Germany and expect that any reservations regarding company-based training will reduce as the number of migration generations increases, thus leading to a subsequent improvement in chances of achieving transition.

- Hypothesis 2c: Indications already in place (Beicht \& Walden, 2014, p. 200) lead us to expect worse chances of progression for young people from all regional origin groups, although opportunities will be poorer for young people from a Turkish or Arab background in particular.

- Hypothesis 2d: Increasing generation status should exert a positive effect on transition to company-based training in all origin groups. 


\section{$4 \quad$ Database and methodological approach}

We conduct our analyses on the basis of data from the German Educational Panel Study (NEPS) (Blossfeld, Roßbach, \& Maurice, 2011) ${ }^{1}$. We used the partial NEPS study "Year 9 start cohort", which collected and continues to collect information on the education and training pathways pursued by young people from Year 9 of general schooling onwards.

Our analyses relate to young people who left a mainstream school after Year 9 in the summer of 2011 or after Year 10 in the summer of 2012. Our database comprises information provided by a total of 5,952 school leavers.

We use regression analyses to investigate the hypotheses formulated in the previous section regarding influence of migrant background of young people on acquisition of school qualifications and on transition to company-based training. The relevant regression models are each calculated four times for this purpose, i.e. using four different variables for migrant background. A brief explanation of these is provided below. In the case of the first variable "migration status", differentiation is only made on the basis of existence or non-existence of a migrant background. The second variable "generation status" contains four gradations of immigration generation for the group of persons from a migrant background. The 1st generation comprises young people who were born abroad rather than in Germany. The 2nd generation encompasses young people born in Germany whose parents immigrated to Germany. A further differentiation is made as to whether both father and mother were born abroad (Generation 2a) or whether this applies in respect of one parent only (Generation 2b). The 3rd migration generation covers young people whose parents were born in Germany but whose grandparents include at least one person who emigrated from abroad. In the case of the third variable "regional origin", four regional origins are differentiated for young people with a migrant background. These are southern Europe, eastern Europe/former Soviet Union, Turkey/other Middle East/North Africa and other regions.

Finally, a fourth variable is also considered by dividing the regional origin groups once more by generation status, although Generations $2 \mathrm{a}$ and $2 \mathrm{~b}$ are conflated in this instance. Because sample sizes are too small (fewer than 30), no statements can be made regarding young people from the 3rd generation who originate from Turkey, other Middle East regions or North Africa. All migration variables are based on the migration generation status variables and group of origin variables generated by the NEPS and made available in a scientific use file (SUF) (Olczyk, Will, \& Kristen, 2016).

Multinomial logistic regression models (Models A1 to A4) were calculated to test the hypotheses relating to acquisition of school qualifications. The level of school leaving quali-

1 This work uses data from the German Educational Panel Study (NEPS) - Year 9 start cohort, doi:10.5157/NEPS:SC4:9.0.0. The NEPS data was collected between 2008 and 2013 as part of a framework programme to promote empirical educational research, which was funded by the Federal Ministry of Education and Research (BMBF). Since 2014, the NEPS has been continued by the Leibniz Institute for Educational Trajectories (LIfBi) at the University of Bamberg in conjunction with a network that covers the whole of Germany. 
fication achieved by the young people when leaving the general school system after Year 9 or Year 10 forms the dependent variable. Alongside the respective migration variables, the social origin of the young people, gender and region of residence (western or eastern Germany) have also been included as independent variables. The function of the latter is merely to act as control variables. Social origin of the young people is taken into account via school education of the parents and occupational status of the father (or of the mother if no information is available for the father) $)^{2}$.

Investigation of the hypotheses relating to successful transition to company-based training takes place on the basis of binary logistical regressions. Only school leavers who expressed an explicit interest in dual vocational education and training are included in the analyses. Successful transition is deemed to have occurred if young people commenced company-based VET within a relatively short period of time after leaving school in the summer of 2011 or 2012. The cut-off point in this regard is March of the respective subsequent year. All other cases are categorised as unsuccessful transitions. We began by calculating models (Models B1.1 to B4.1) in which social origin of the young people, school qualifications, gender, region of residence, a variable relating to the mathematical competence of the young persons ${ }^{3}$ and a variable which contains an indicator of the training market situation in the region of residence in the year of leaving school were included as control variables.

Because we know from existing investigations that occupational interests of young people also exert a major influence on successful transition to dual training (Beicht and Walden 2015b, 2017a), we conducted the regression analyses another time using three supplementary variables relating to occupations forming an object of application by the young people ${ }^{4}$ (Models B1.2 to B4.2). Firstly, account was taken of the type of these occupations. A distinction was drawn between production and service occupations in this regard. Secondly, we formed a variable which expresses whether the young people were in possession of a school qualification which was a match for the requirements level of the occupations or whether the qualification tended to be too low or too high in this respect. We further included an indicator of the training market situation in the respective occupations. These variables also exclusively fulfil the function of control variables.

Some individual independent variables taken into account in the regression models exhibit a relatively high proportion of missing values. This applies in particular to information regarding the socio-economic status of the father or mother. For this reason, data was supplemented by multiple imputation ${ }^{5}$.

2 The occupational status of the father or of the mother is mapped using the International Socio-economic Index of Occupatio nal Status (ISEI-08), which is already included as a variable in the NEPS data.

${ }^{3}$ In the NEPS, weighted maximum likelihood estimates (WLE) were calculated as estimators of competence. These are available in the SUF.

${ }_{4}$ In the NEPS surveys, precise information was collected for a maximum of two occupations.

5 Analyses including the multiple imputations were conducted using the statistical software Stata (Impute missing values using chained equations). 20 imputations were carried out $(\mathrm{m}=20)$. 
The particular characteristics of the sample need to be taken into account when conducting regression analyses on the basis of data from the partial NEPS study "Year 9 start cohort". It is a disproportionately stratified cluster sample. We therefore used the statistical software Stata to weight the dataset and to take the clustering of the sample into account. We report the results of the logistic regression models calculated as average marginal effects (AME) ${ }^{6}$.

\section{$5 \quad$ Results of the analyses}

$37 \%$ of school leavers who exited the general school system in 2011 or 2012 after Year 9 or Year 10 at a mainstream school exhibit a migrant background. One fifth of these young migrants form part of the 1st migration generation, i.e. they were born abroad (cf. Table 1).

Table 1: Young people from a migrant background who left the general school system in 2011 or 2012 after Year 9 or Year 10, differentiated by generation status and by regional origin (distributions in percent)

\begin{tabular}{|c|c|c|c|c|c|}
\hline \multirow[b]{2}{*}{ Regional origin } & \multicolumn{4}{|c|}{ Generation status } & \multirow[b]{2}{*}{ Total } \\
\hline & $\begin{array}{l}\text { Born abroad } \\
\text { (Gen. 1) }\end{array}$ & $\begin{array}{c}\text { Born in } \\
\text { Germany, } \\
\text { both parents } \\
\text { born abroad } \\
\text { (Gen. 2a) }\end{array}$ & $\begin{array}{l}\text { Born in } \\
\text { Germany, one } \\
\text { parent born } \\
\text { abroad } \\
\text { (Gen. 2b) }\end{array}$ & $\begin{array}{c}\text { Born in } \\
\text { Germany, } \\
\text { parents born } \\
\text { in Gemmany, } \\
\text { at least one } \\
\text { grandparent } \\
\text { born abroad } \\
\text { (Gen. 3) }\end{array}$ & \\
\hline Southern Europe & 14.9 & 14.4 & 21.7 & 14.4 & 16.2 \\
\hline Eastern Europe, former Soviet Union & 57.3 & 29.0 & 24.1 & 53.9 & 39.9 \\
\hline Turkey, other Middle East and North Africa & 14.3 & 39.4 & 21.5 & 2.3 & 20.6 \\
\hline Other regions or not attributable & 13.5 & 17.2 & 32.7 & 29.3 & 23.3 \\
\hline Total & 100.0 & 100.0 & 100.0 & 100.0 & 100.0 \\
\hline \multirow[b]{2}{*}{ Generation status } & \multicolumn{4}{|c|}{ Regional origin } & \multirow[b]{2}{*}{ Tota } \\
\hline & $\begin{array}{l}\text { Southern } \\
\text { Europe }\end{array}$ & $\begin{array}{c}\text { Eastern } \\
\text { Europe, } \\
\text { former Soviet } \\
\text { Union }\end{array}$ & $\begin{array}{c}\text { Turkey, other } \\
\text { Middle East } \\
\text { and North } \\
\text { Africa }\end{array}$ & $\begin{array}{l}\text { Other regions } \\
\text { or not } \\
\text { attributable }\end{array}$ & \\
\hline Born abroad (Gen. 1) & 18.1 & 28.3 & 13.7 & 11.5 & 19.8 \\
\hline $\begin{array}{l}\text { Bom in Germany, both parents born abroad } \\
\text { (Gen. 2a) }\end{array}$ & 27.4 & 22.3 & 58.9 & 22.8 & 30.8 \\
\hline $\begin{array}{l}\text { Born in Germany, one parent born abroad } \\
\text { (Gen. 2b). }\end{array}$ & 31.2 & 14.1 & 24.4 & 32.8 & 23.3 \\
\hline $\begin{array}{l}\text { Born in Germany, parents born in Germany, } \\
\text { at least one grandparent born abroad (Gen. 3) }\end{array}$ & 23.2 & 35.3 & 2.9 & 33.0 & 26.1 \\
\hline Total & 100.0 & 100.0 & 100.0 & 100.0 & 100.0 \\
\hline
\end{tabular}

Weighted results, unweighted sample size: 2,245 .

Source: National Educational Panel Study, Start cohort 4 (10.5157/NEPS:SC4:9.0.0), calculations by the authors.

Over half are from the 2 nd generation. Just over a quarter can be allocated to the 3 rd generation. Two fifths of school leavers from a migrant background originate from families from eastern Europe (referred to below as "eastern European origin") and around a fifth from families from Turkey, other Middle East and North Africa (referred to below as "Turkish or

6 For categorical variables, the AME state by how many percentage points the average probability for the event of interest differs in the observed group from the probability of the respective reference group. 
Arab background"). The lowest proportion of young migrants is those of southern European origin (16\%). A total of $70 \%$ of the school leavers from a migrant background learned to speak German in their families whilst they were children. By way of contrast, the remaining group spoke only a foreign language (Table 2).

Table 2: Native language and citizenship of young people from a migrant background who left the general school system in 2011 or 2012 after Year 9 or Year 10, differentiated by generation status and by regional origin (distributions in percent)

\begin{tabular}{|c|c|c|c|c|c|c|c|c|c|}
\hline \multirow[b]{2}{*}{$\begin{array}{l}\text { Native } \\
\text { language/nationality }\end{array}$} & \multirow[b]{2}{*}{$\begin{array}{l}\text { From } \\
\text { migrant } \\
\text { back- } \\
\text { ground in } \\
\text { total }\end{array}$} & \multicolumn{4}{|c|}{ Generation status } & \multicolumn{4}{|c|}{ Regional origin } \\
\hline & & $\begin{array}{c}\text { Born } \\
\text { abroad } \\
\text { (Gen. 1) }\end{array}$ & $\begin{array}{l}\text { Born in } \\
\text { Germany, } \\
\text { both } \\
\text { parents } \\
\text { born } \\
\text { abroad } \\
\text { (Gen. 2a) }\end{array}$ & $\begin{array}{c}\text { Born in } \\
\text { Germany, } \\
\text { one parent } \\
\text { born } \\
\text { abroad } \\
\text { (Gen. } 2 \mathrm{~b} \text { ) }\end{array}$ & $\begin{array}{c}\text { Born in } \\
\text { Germany, } \\
\text { parents born } \\
\text { in Germany, } \\
\text { at least one } \\
\text { grandparent } \\
\text { born abroad } \\
\text { (Gen. } 3 \text { ) }\end{array}$ & $\begin{array}{l}\text { Southern } \\
\text { Europe }\end{array}$ & $\begin{array}{l}\text { Eastern } \\
\text { Europe, } \\
\text { former } \\
\text { Soviet } \\
\text { Union }\end{array}$ & $\begin{array}{c}\text { Turkey, } \\
\text { other } \\
\text { Middle } \\
\text { East } \\
\text { and } \\
\text { North } \\
\text { Africa }\end{array}$ & $\begin{array}{l}\text { Other } \\
\text { regions } \\
\text { or not } \\
\text { attribu- } \\
\text { table }\end{array}$ \\
\hline \multicolumn{10}{|l|}{ Native language } \\
\hline German only & 40.7 & 4.7 & 15.5 & 48.9 & 90.4 & 35.6 & 48.7 & 7.1 & 60.4 \\
\hline German and foreign & 29.2 & 23.2 & 43.6 & 39.8 & 7.4 & 34.0 & 24.9 & 38.8 & 24.9 \\
\hline Foreign only & 29.2 & 70.9 & 39.6 & 10.7 & 2.1 & 29.5 & 25.9 & 53.3 & 13.3 \\
\hline Missing information & 0.9 & 1.2 & 1.4 & 0.7 & 0.1 & 0.9 & 0.4 & 0.9 & 1.4 \\
\hline \multicolumn{10}{|l|}{ Citizenship } \\
\hline German only & 64.6 & 40.5 & 55.9 & 66.4 & 91.3 & 47.3 & 81.9 & 38.5 & 70.0 \\
\hline German and foreign & 11.3 & 18.5 & 7.7 & 19.1 & 3.4 & 11.2 & 9.5 & 11.5 & 14.4 \\
\hline Foreign only & 21.1 & 37.7 & 34.7 & 11.3 & 1.2 & 38.3 & 6.0 & 47.8 & 11.3 \\
\hline Missing information & 3.0 & 3.4 & 1.8 & 3.2 & 4.0 & 3.2 & 2.6 & 2.2 & 4.3 \\
\hline $\begin{array}{l}\text { Total (per } \\
\text { characteristic) }\end{array}$ & 100.0 & 100.0 & 100.0 & 100.0 & 100.0 & 100.0 & 100.0 & 100.0 & 100.0 \\
\hline
\end{tabular}

Weighted results, unweighted sample size: 2,245 .

Source: National Educational Panel Study, Start cohort 4(10.5157/NEPS:SC4:9.0.0), calculations by the authors.

As generation status increases, German is more likely to be the native tongue. There are, however, major differences by region of origin. Young people from a Turkish or Arab background are least likely to have learned the German language in their families. Just over three quarters of the young migrants hold German citizenship, although proportions once again vary widely by generation status and region of origin.

\subsection{Acquisition of school qualifications}

Young migrants are significantly more likely than young people not from a migrant background to leave the school system after lower secondary level with a basic or qualifying lower secondary school certificate. They are also substantially less likely than their non-migrant counterparts to achieve an intermediate secondary school leaving certificate (cf. Table 3). However, school qualifications achieved improve markedly as generation status rises. By the 
3rd generation, the average performance of young migrants is just as good as that of nonmigrants. School success differs considerably by regions of origin. Whereas young people from an eastern European background are relatively likely to achieve an intermediate school certificate, those of Turkish or Arab origin predominantly leave school with a lower secondary certificate. Comparatively large numbers within the latter group fail to achieve a school leaving certificate at all.

Table 3: School qualification of young people who left the general school system in 2011 or 2012 after Year 9 or Year 10, differentiated by generation status and by regional origin (distributions in percent)

\begin{tabular}{|c|c|c|c|c|c|c|c|c|c|c|}
\hline \multirow[b]{2}{*}{ School qualification } & \multirow[b]{2}{*}{$\begin{array}{l}\text { From } \\
\text { migrant } \\
\text { back- } \\
\text { ground in } \\
\text { total }\end{array}$} & \multicolumn{4}{|c|}{ Generation status } & \multicolumn{4}{|c|}{ Regional origin } & \multirow[b]{2}{*}{$\begin{array}{l}\text { No } \\
\text { migrant } \\
\text { back- } \\
\text { ground }\end{array}$} \\
\hline & & $\begin{array}{c}\text { Born } \\
\text { abroad } \\
\text { (Gen. 1) }\end{array}$ & $\begin{array}{l}\text { Born in } \\
\text { Germany, } \\
\text { both } \\
\text { parents } \\
\text { born } \\
\text { abroad } \\
\text { (Gen. } 2 \mathrm{a})\end{array}$ & $\begin{array}{c}\text { Born in } \\
\text { Germany, } \\
\text { one parent } \\
\text { born } \\
\text { abroad } \\
\text { (Gen. } 2 \mathrm{~b})\end{array}$ & $\begin{array}{l}\text { Born in } \\
\text { Germany, } \\
\text { parents born } \\
\text { in Germany, } \\
\text { at least one } \\
\text { grandparent } \\
\text { born abroad } \\
\text { (Gen. 3) }\end{array}$ & $\begin{array}{l}\text { Southern } \\
\text { Europe }\end{array}$ & $\begin{array}{c}\text { Eastern } \\
\text { Europe, } \\
\text { former } \\
\text { Soviet } \\
\text { Union }\end{array}$ & $\begin{array}{l}\text { Turkey, } \\
\text { other } \\
\text { Middle } \\
\text { East and } \\
\text { North } \\
\text { Africa }\end{array}$ & $\begin{array}{l}\text { Other } \\
\text { regions } \\
\text { or not } \\
\text { attribu- } \\
\text { table }\end{array}$ & \\
\hline $\begin{array}{l}\text { No lower secondary } \\
\text { school leaving } \\
\text { certificate }\end{array}$ & 3.8 & 4.2 & 3.6 & 4.5 & 3.1 & 2.4 & 2.8 & 8.3 & 2.5 & 2.3 \\
\hline $\begin{array}{l}\text { Basic lower } \\
\text { secondary school } \\
\text { leaving certificate }\end{array}$ & 25.3 & 33.5 & 28.6 & 23.3 & 17.0 & 27.0 & 21.9 & 27.7 & 27.7 & 20.4 \\
\hline $\begin{array}{l}\text { Qualifying lower } \\
\text { secondary school } \\
\text { leaving certificate }\end{array}$ & 15.8 & 18.4 & 17.5 & 16.4 & 11.4 & 15.6 & 12.7 & 23.9 & 14.3 & 11.3 \\
\hline $\begin{array}{l}\text { Intermediate school } \\
\text { leaving certificate }\end{array}$ & 55.1 & 43.9 & 50.4 & 55.9 & 68.5 & 55.0 & 62.6 & 40.1 & 55.6 & 66.0 \\
\hline $\begin{array}{l}\text { Total (per } \\
\text { characteristic) }\end{array}$ & 100.0 & 100.0 & 100.0 & 100.0 & 100.0 & 100.0 & 100.0 & 100.0 & 100.0 & 100.0 \\
\hline
\end{tabular}

Weighted results, unweighted sample size: 5,952.

Source: National Educational Panel Study, Start cohort 4 (10.5157/NEPS:SC4:9.0.0), calculations by the authors.

Multinomial regression models are now used to investigate whether school qualifications acquired deviate between school leavers from and not from a migrant background and between the various migrant groups even if we control for important further cause variables (cf. Table 4). These models are used to test hypotheses $1 \mathrm{a}$ to $1 \mathrm{~d}$ posed with regard to acquisition of school qualifications. 
Table 4: Influences on the acquisition of school leaving qualifications in the case of young people who left the general school system in 2011 or 2012 after Year 9 or Year 10 - results of multinomial regression models (average marginal effects, AME)

\begin{tabular}{|c|c|c|c|}
\hline \multirow[b]{2}{*}{ Cause variables } & \multicolumn{3}{|c|}{ Models $A 1$ to $A 4$} \\
\hline & $\begin{array}{c}\text { No qualification } \\
\text { higher than basic } \\
\text { lower secondary } \\
\text { school leaving } \\
\text { certificate }\end{array}$ & $\begin{array}{l}\text { Qualifying lower } \\
\text { secordlary schood } \\
\text { leaving certificate }\end{array}$ & $\begin{array}{l}\text { Intermediate school } \\
\text { leaving certificate }\end{array}$ \\
\hline \multicolumn{4}{|l|}{$\begin{array}{l}\text { Migration background of the young person } \\
\text { Morlel } \mathrm{Al}^{1}\end{array}$} \\
\hline \multicolumn{4}{|l|}{ Migrations status fref- no migrations backgnouad) } \\
\hline - With migration background & $.052^{m+\infty}$ & $045^{20 *}$ & $-097 * \cdots$ \\
\hline \multicolumn{4}{|l|}{ Genervation statues (ref: mo miggratican baskgrownd? } \\
\hline - Bom abroad (Ger. I) & .121 ken & $.076^{*} * *$ & $-196 \times+4$ \\
\hline - Bom in Germany, both parents born abroad (Gen. 2a) & $061^{\cdots \infty}$ & $064 * 0 \%$ & $-125 \times 0 x$ \\
\hline - Bom in Germany, one parent born alread (Cien. 2b) & $.050^{*}$ & $053^{* 0}$ & $-102^{* * * *}$ \\
\hline $\begin{array}{l}\text { - Bom in Germany, parents bort in Germany, at least one } \\
\text { grandparent bom abroad (Gen. 3) }\end{array}$ & -.008 & -006 & .014 \\
\hline \multicolumn{4}{|l|}{ Model $A 3^{\top}$} \\
\hline \multicolumn{4}{|l|}{ 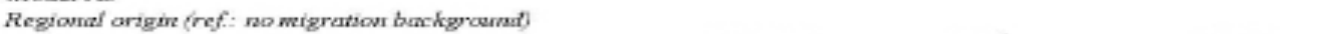 } \\
\hline - Southern Europe & $.093^{* 0 \times x}$ & $038^{+}$ & $-131 \times \times \times$ \\
\hline - Eastem Europe, former Soviet Union & 018 & .016 & $-035^{+}$ \\
\hline - Turkey, other Middle East and North Africa & $.094^{\text {nom }}$ & $-103 * \cdots$ & $-197 * 0 *$ \\
\hline - Other regions (or not attributable) & $.038^{+}$ & $048 * 0$ & $-086 *-\infty$ \\
\hline \multirow{2}{*}{\multicolumn{4}{|c|}{ 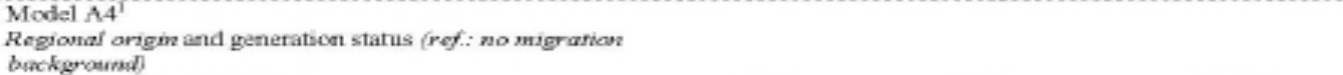 }} \\
\hline & & & \\
\hline - Southern Europe - Gien. I & $-175^{+\infty}$ & 018 & $-194+\infty$ \\
\hline - Scuthern Eucpe - Gen. 2 & $.101^{\infty *}$ & $072 \times *$ & $-174^{x \times *}$ \\
\hline - Southern Europe - Gen. 3 & 007 & -0.41 & 034 \\
\hline - Eastem Europe, former Soviet Union-Gen 1 & $.111^{\mathrm{m}}$ & $077 * 0$ & $-188 * a x$ \\
\hline - Eastem Europe, former Soviet Union - Gen 2 & .006 & 002 & -008 \\
\hline - Eastem Europe, former Soviet Union - Gen. 3 & $-0.45^{+}$ & -017 & $063 *$ \\
\hline - Turkey, other Middle East and North Africa-Gen. I & $-135 *$ & $-164 * *$ & $-299+\cdots$ \\
\hline - Tukey, other Middle East and North Africa - Gen. 2 & $080^{\cdots+}$ & $095 * \infty$ & $-181^{* 0 *}$ \\
\hline - Turkey, othor Middle East and North Africa - Gen. $3^{2}$ & $(-129)$ & $(.047)$ & $(-156)$ \\
\hline - Ober regions (or not attributable) - Gen. 1 & .090 & .038 & $-118^{+}$ \\
\hline - Other regions (or not attributable) - Ger. 2 & .034 & $.067 * \%$ & $-101 * 0$ \\
\hline - Other regions (or not attributable) - Gen. 3 & 033 & 024 & -057 \\
\hline \multicolumn{4}{|l|}{ Social origin of the youmg persoer: } \\
\hline \multicolumn{4}{|l|}{ 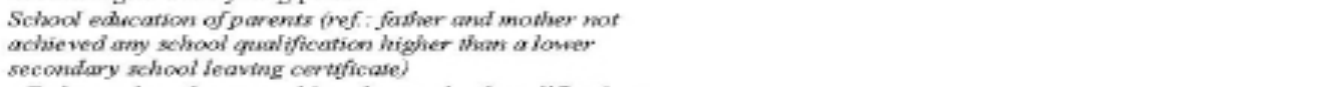 } \\
\hline $\begin{array}{l}\text { - Father and mother not achieved any school qualification } \\
\text { higher than an irfertmediate secondary school leaving } \\
\text { certificate }\end{array}$ & $-.058 * \bullet$ & -.013 & $.071+\infty$ \\
\hline $\begin{array}{l}\text { - Father or mother with upper secondary school leaving } \\
\text { certificate or higher education qualification. }\end{array}$ & $-096 * 0 *$ & $-053^{* 0}$ & $149 \div 04$ \\
\hline Socio-eccricenic status of the father (ISEI-08) ${ }^{2}$ & $-013^{\cdots \infty}$ & -006 & $019 x-a x$ \\
\hline \multicolumn{4}{|l|}{ Gender of the young person/region of residence: } \\
\hline \multicolumn{4}{|l|}{ Gencier (reff: male) } \\
\hline - Female & $-037^{+*}$ & $-032 *+$ & $069+\infty$ \\
\hline Place of residence (nef: Western Germany) & & & \\
\hline - Eastem Gennany & $-104^{x<x}$ & $-.027^{+}$ & $131 \times \times *$ \\
\hline \multicolumn{4}{|c|}{ 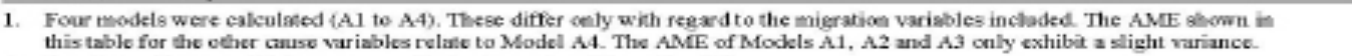 } \\
\hline \multicolumn{4}{|c|}{ 2. Resalits not interpretable because sample size is too low (fewe than 30). } \\
\hline \multicolumn{4}{|c|}{ 3. Incease in the ISEI-C8 value by 10 points reqectively. } \\
\hline \multicolumn{4}{|c|}{$\begin{array}{l}\text { Results of multiple imputatice estimates }(\mathrm{m}-20) \text {, weighted dataset (unweighted sample size: } 5,952 \text {. } \\
\text { Significance level }{ }^{+} p<0.1, * p<0.05, * p<0.01,+\cdots p<0.001 \text { (two-way test). }\end{array}$} \\
\hline \multicolumn{4}{|c|}{ Significance level ${ }^{+} p<0.1, p<0.05, * p<0.01, * p<<0.001$ (two-way test). } \\
\hline Source: National Educational Panel Stody, Start cohort 4 (1) & $5157 /$ NEPS SC49. & ent & \\
\hline
\end{tabular}

It is revealed that the overall group of young migrants is 5 percentage points more likely than the comparative group not from a migrant background to leave general schooling after lower secondary level with no qualification higher than the basic or qualifying lower secondary 
school certificate (see Model A1). By way of contrast, young people from a miggrant background are 10 percentage points less likely to achieve an intermediate secondary school leaving certificate. Hypothesis 1a, which assumed lower levels of educational success by young migrants in the general school system, is thus confirmed.

As generation status increases, there is a reduction in the differences that can be identified between young migrants and non-migrants in terms of probability of concluding general schooling after lower secondary level having achieved a certain school qualification (see Model A2). In the 1st generation, young people from a migrant background are 20 percentage points less likely to acquire an intermediate school leaving certificate. This difference reduces significantly in the 2 nd generation, although it remains at -13 percentage points (Generation $2 \mathrm{a})$ and -10 percentage points respectively (Generation $2 \mathrm{~b}$ ). In the 3rd generation, no disadvantage vis-à-vis non-migrants is any longer discernible. Hypothesis $1 \mathrm{~b}$, in which we presumed that chances of obtaining an intermediate secondary school leaving certificate improve in line with increasing generation status, is therefore shown to be applicable.

If we differentiate for regional origin of the young migrants, all four origin groups display a lower probability of leaving general schooling with an intermediate school qualification as compared to non-migrants (see Model A3). Young people of Turkish or Arab origin are the group least likely to achieve an intermediate secondary school leaving certificate (-20 percentage points). As expected, therefore, the first part of Hypothesis $1 \mathrm{c}$ is confirmed. However, the further assumption that results for the other origin groups should not differ significantly is not quite borne out. The difference between migrants of southern European origin and nonmigrants in terms of the probability of obtaining an intermediate school qualification is -13 percentage points, whereas those from an eastern European background display a difference of only -4 percentage points.

If migration generation is considered alongside regional origin, a reduction in differences relating to the acquisition of school qualifications as compared to non-migrants can be identified in all origin groups as generation status increases (see Model A4). This is in line with the assumption made in Hypothesis $1 \mathrm{~d}$. Nevertheless, development is definitely different within the individual origin groups. Although the probability that young people from a Turkish or Arab background will obtain an intermediate secondary school leaving certificate increases significantly between the 1 st and 2 nd generations, the difference to non-migrants remains at a high level. In the case of young people of eastern European origin, on the other hand, the difference vis-à-vis non-migrants has already disappeared by the 2 nd generation. In the $3 r d$ generation, it is even the case that they are significantly more likely to achieve an intermediate secondary qualification. 


\subsection{Transition to company-based training}

Compared to non-migrants, young people from a migrant background are less likely to aspire to dual vocational education and training if they leave general schooling after lower secondary level (cf. Figure 1). Interest in vocational training is less marked amongst all origin groups compared to non-migrants. The lowest level of interest in vocational education and training is recorded amongst school leavers of Turkish or Arab origin or of other regions. These groups are also comparatively unlikely to aspire to dual VET. By way of contrast, young people from a southern European background are relatively likely to wish to commence vocational or dual training upon completion of schooling.

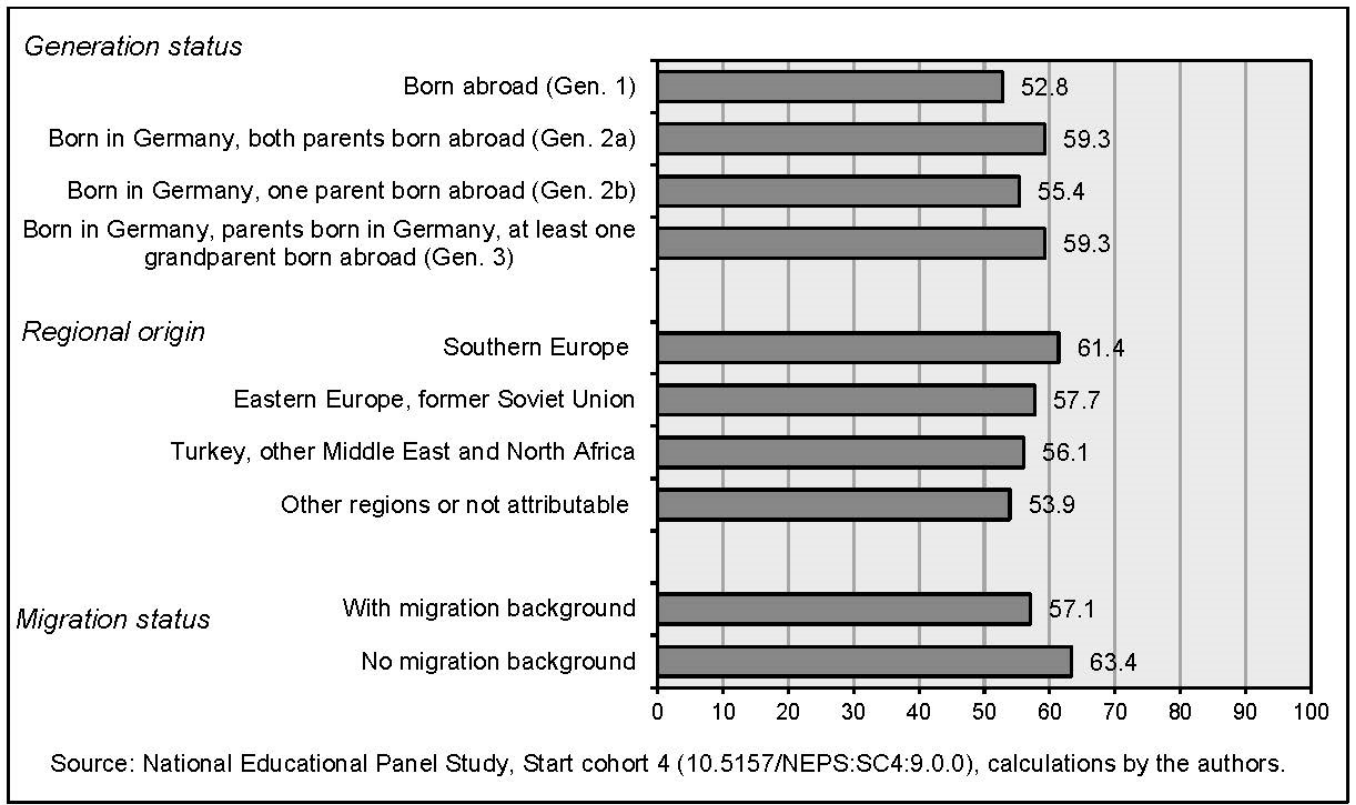

Fig. 1: Explicit interest in dual vocational education and training of young people who left the general school system in 2011 or 2012 after Year 9 or Year 10, differentiated by generation status and by regional origin (distributions in percent)

Only half of young people from a migrant background who leave the general school system after lower secondary level with the aspiration of entering dual vocational education and training succeed in making this transition, i.e. by progressing to company-based training within a relatively short period of time (cf. Figure 2). 


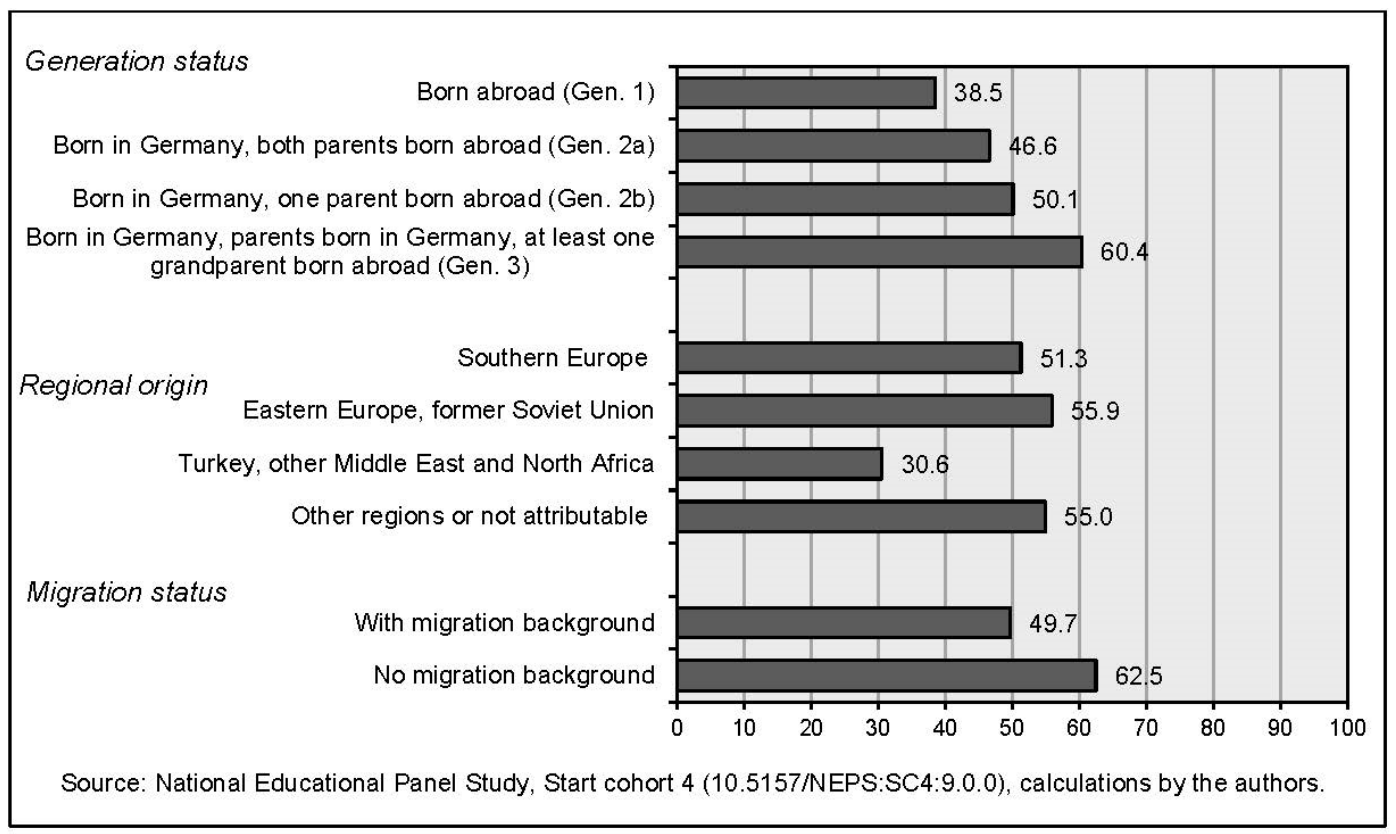

Fig. 2: Progression to company-based vocational education and training by young people who left the general school system in 2011 or 2012 after Year 9 or Year 10 and had an explicit interest in dual training, differentiated by generation status and by regional origin (progression rates in percent)

By way of contrast, $63 \%$ of the corresponding school leavers not from a migrant background were able to find a company-based training place. Although the progression rate for young migrants in the 1st generation is very low, it increases considerably in line with rising generation status and is only slightly lower than the rate for non-migrants in the 3rd generation. If we differentiate by regional origin, it is revealed that young people from a Turkish or Arab background are extremely unlikely to make a successful transition to company-based training. The other origin groups perform considerably better in this regard. The best prospects are enjoyed by school leavers of eastern European origin, closely followed by those from other regions of origin. If we undertake a differentiated consideration of the origin groups by generation status, almost all groups display a lower progression rate than young people not from a migrant background. However, young people of eastern European origin form an exception in this regard. The progression rate of this group in the $3 \mathrm{rd}$ generation is even shown to be above that of persons not from a migrant background (not depicted in the figure).

Successful transition to company based training is influenced by a diverse range of factors, particularly school qualifications and occupational interests. The intention now is to use logistic regression models to investigate whether variances with regard to making a successful 
transition continue to exist between school leavers from and not from a migrant background and between the migrant groups if a large number of significant cause variables are also taken into account (cf. Table 5). Hypotheses $2 \mathrm{a}$ to $2 \mathrm{~d}$ will be tested on this basis.

Table 5: Influences on progression to company-based vocational education and training by young people who left the general school system in 2011 or 2012 after Year 9 or Year 10 and had an explicit interest in dual training - results of binary logistic regression models (average marginal effects, $A M E$ )

\begin{tabular}{|c|c|c|}
\hline \multirow[b]{2}{*}{ Cause variables } & Models B1.I to B4.I & Models B1 2 to B4.2 \\
\hline & $\begin{array}{l}\text { 1 Occupations forming a } \\
\text { possible object of application } \\
\text { not taken into account }\end{array}$ & $\begin{array}{l}2 \text { Occupations fonming a } \\
\text { possible object of application } \\
\text { takent into aooount }\end{array}$ \\
\hline \multicolumn{3}{|l|}{ Migration background of the young person: } \\
\hline \multicolumn{3}{|l|}{ Model BI.1/BI.21 } \\
\hline \multicolumn{3}{|l|}{ Migrotion status (ref: no migration bacharosiend) } \\
\hline - With migration background & $-096^{*+4}$ & $-.085 *+\infty$ \\
\hline \multicolumn{3}{|l|}{ Model B2.1/B2.2 } \\
\hline \multicolumn{3}{|l|}{ Generation stanes (ref: no migrantion backgrownd) } \\
\hline - Bom abroad (Gen. 1) & -.150000 & $-.1370 \times 6$ \\
\hline - Bom in Germany, both parents bom abroad (Gen. 2a) & $-.1350+2$ & $-.111 \mathrm{kx*}$ \\
\hline - Bom in Germany, one parent bom atroad (Gen. 2b) & $-.085 \cdots$ & $-.072 *$ \\
\hline - Bom in Germany, parents born in Germany, at least one & -.026 & -.033 \\
\hline \multicolumn{3}{|l|}{ Model B3.1/B3.2 } \\
\hline \multicolumn{3}{|l|}{ Regionid arigin (ref: no migration buckground) } \\
\hline - Scuthern Europe & $-.083^{*}$ & $-.075 *$ \\
\hline - Eastem Europe, former Soviet Union & $-064^{\mathrm{x} *}$ & $-0.62^{\times *}$ \\
\hline - Turkey, other Midde East and North Africa & $-.159 \cdot+4$ & $-131 \cdots$ \\
\hline - Other regions or not attributable & $-.110^{0000}$ & $-.096 \times 6^{2 *}$ \\
\hline \multicolumn{3}{|l|}{ Model B 4.1/B4.2 ${ }^{\mathrm{i}}$} \\
\hline \multicolumn{3}{|l|}{$\begin{array}{l}\text { Regiopul origin and generation status (ref.: no migration } \\
\text { buckgrouand) }\end{array}$} \\
\hline - Southern Europe - Gen 1 & $-.138^{+}$ & $-.140^{\circ}$ \\
\hline - Scuthern Europe-Gen. 2 & -.063 & -.041 \\
\hline - Southern Europe-Gen 3 & -.106 & $-.133^{*}$ \\
\hline - Eastem Euroje, former Soviet Union - Gen. 1 & $-.170 * 2 *$ & $-.161^{* k e}$ \\
\hline - Eastem Earope, former Soviat Union-Gen. 2 & $-082^{\circ}$ & $-071^{*}$ \\
\hline - Eastem Europe, former Soviet Union - Gen. 3 & .042 & .031 \\
\hline - Turkey, other Midđe East and North Africa - Gen. I & -.100 & -.053 \\
\hline - Turkey, other Midde East and North Africa-Gen. 2 & $-.175000 \%$ & $-.150^{\circ \times 6}$ \\
\hline - Turkey, other Midde East and North Africa - Gen. $3^{2}$ & $(-079)$ & $(-060)$ \\
\hline - Other regions (or not attributable) - Ger. $1^{2}$ & $(-.143)$ & $(-.132)$ \\
\hline - Other regions (or not attributable) - Gen. 2 & $-.123^{\circ *}$ & $-.107^{*}$ \\
\hline - Other regions (or not attritbutable) - Gen. 3 & $-.090^{+}$ & $-.078^{+}$ \\
\hline \multicolumn{3}{|l|}{ Social origin of the young person: } \\
\hline \multicolumn{3}{|l|}{ 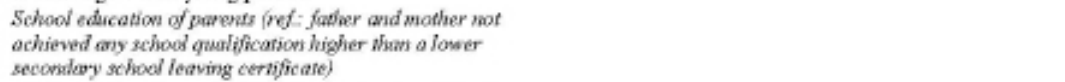 } \\
\hline $\begin{array}{l}\text { - Father and mother not achiavod ary school qualification } \\
\text { higher than an intemediate secondary school leaving } \\
\text { oertificate }\end{array}$ & -013 & -.017 \\
\hline $\begin{array}{l}\text { - Father of modher with upper secondary schood leaving } \\
\text { oertificate or higher education qualification }\end{array}$ & -.031 & -.036 \\
\hline $\begin{array}{l}\text { Socio-economic status of the father (alternatively of the } \\
\text { mother) (ISEI-08) }\end{array}$ & -.003 & -.001 \\
\hline \multicolumn{3}{|l|}{$\begin{array}{l}\text { School qualification of the young personimathematical } \\
\text { competence: }\end{array}$} \\
\hline \multicolumn{3}{|l|}{$\begin{array}{l}\text { School qualification inef: not achieved lower secondary } \\
\text { school leaving certificatey }\end{array}$} \\
\hline - Basic lower secondary school leaving certificate & $263^{* 00 *}$ & $.277 \% \times *$ \\
\hline - Qualifying lower secondary school leavirg certificate & $343 * 0$ & $.366 * \cdots$ \\
\hline - Irternnedate school leaving certificate & $385^{n+\infty}$ & $340^{5 \times n}$ \\
\hline (Worse) average mork on firwl report & $-0,00^{n+*}$ & $-094^{\mathrm{n} \times \mathrm{n}}$ \\
\hline Mathematical competence (WLE) & $.026 *$ & $.026^{*}$ \\
\hline
\end{tabular}




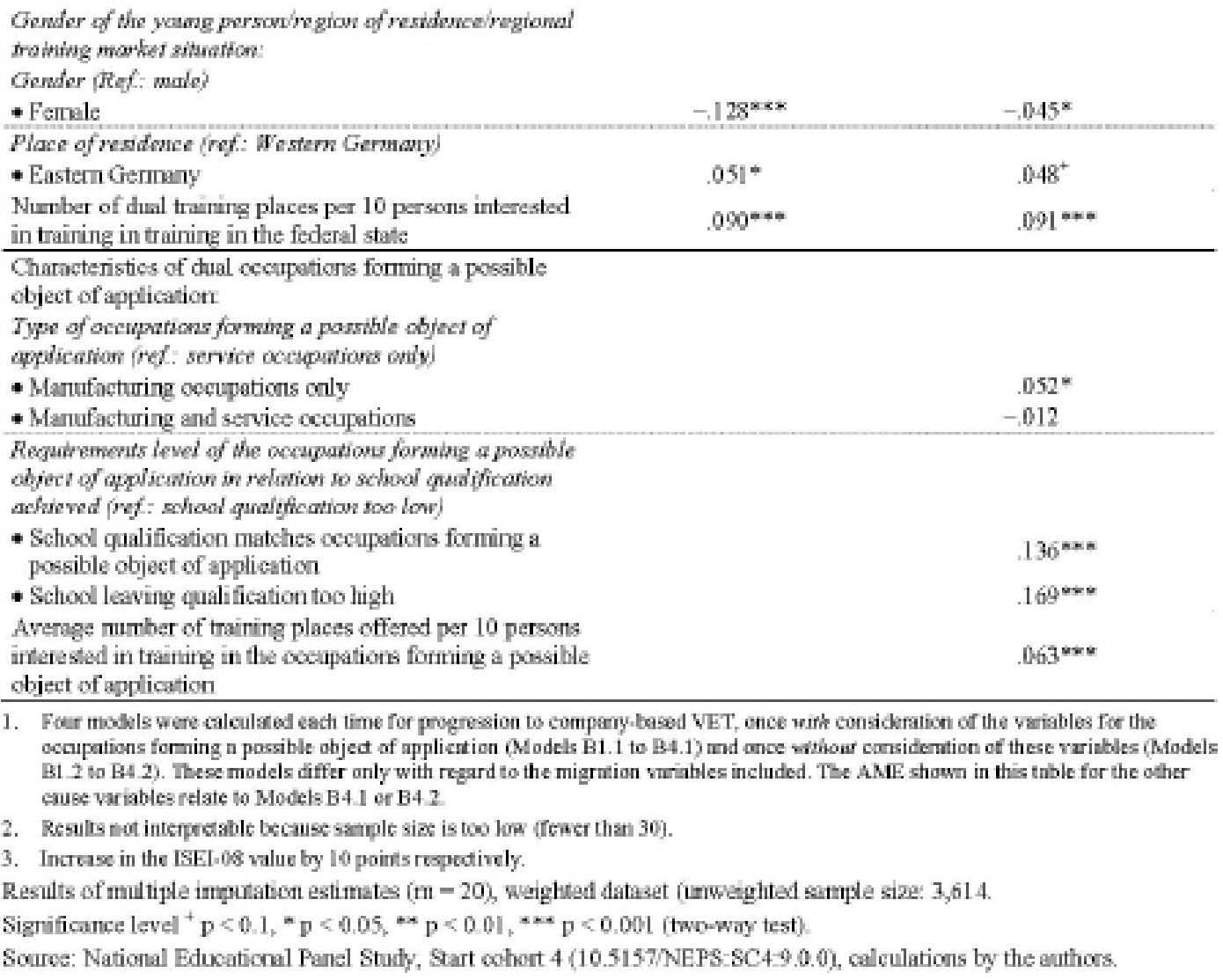

The overall group of school leavers from a migrant background who are interested in dual training is 10 percentage points less likely to progress to company-based vocational education and training than their counterparts not from a migrant background if occupational interests are not taken into account (see Model B1.1). If we also include important characteristics of the occupations for which young people have applied, the difference falls only slightly to 9 percentage points (see Model B1.2). Divergent occupational interests are thus only responsible for the lower probability of success by migrants to a very limited extent. These results are in line with Hypothesis 2a, in which we assumed that a migrant background would display a negative effect on chances of transition to company-based training even if multifarious influencing factors were taken into account.

If we differentiate by migration generations, it is possible to identify that the disadvantages in opportunity suffered by young migrants with regard to company-based training diminish as generation status rises. If the occupational interests of the school leavers are included in the analyses, school leavers from a 1st generation migrant background are 14 percentage points less likely to progress to company-based training than those not from a migrant background (see Model B2.2). In the 2nd generation, this difference reduces to -11 percentage 
points (Generation 2a) and to -7 percentage points respectively (Generation $2 \mathrm{~b}$ ). In the $3 \mathrm{rd}$ generation, no significant variance exists any longer. Slightly larger differences are revealed without controlling for occupational interests (see Model B2.1). The supposition formulated in Hypothesis $2 \mathrm{~b}$ that any reservations regarding company-based training will reduce as the number of migration generations increases, thus leading to a subsequent improvement in chances of achieving transition, is therefore shown to be applicable.

If the young migrants are differentiated by regions of origin, all four origin groups are shown to be less likely to progress to company-based training compared to non-migrants (see Models B3.1/B3.2). In the analyses including and not including occupational interests, school leavers from a Turkish or Arab background exhibit the lowest level of probability of transition. By way of contrast, young people of eastern European origin are least likely to be affected by disadvantages in opportunity. Hypothesis $2 c$, in which we expected that chances of progression would be worse for all origin groups and poorer for young people from a Turkish or Arab background in particular, is thus confirmed.

If additional differentiation by migration generation is conducted, very different developments can be identified in the four regional origin groups (see Models B4.1/B4.2). The assumption made in Hypothesis $2 \mathrm{~d}$ that chances of transition would improve for all origin groups in line with rising generation status is only discernible for young people of eastern $\mathrm{Eu}$ ropean origin. The major disadvantages in opportunity that are present in the 1st generation are alleviated significantly in the 2 nd generation. By the 3 rd generation, no significant difference compared to non-migrants is any longer exhibited. By way of contrast, the probability of obtaining a company-based training place is very low in the 2 nd generation of the Turkish or Arab migrant group, whereas this group does not display any significant variance to nonmigrants in the 1st generation. If occupational interests are taken into account, the southern European origin group presents the opposite picture. In this case, significant disadvantages in opportunity exist in the 1st and 3rd generations, whilst these are not present in the 2nd generation. In overall terms, the expectation formulated in Hypothesis $2 \mathrm{~d}$ that chances would increase in all origin groups in line with rising generation status is largely shown not to apply.

\section{Summary and conclusions}

In average terms, young people in Germany who are from a migrant background acquire lower level school qualifications than their counterparts not from a migrant background and also have worse chances than the latter of successfully progressing to company-based vocational education and training. This applies even if other important influencing factors such as social origin are taken into account. 
If we consider acquisition of a general school qualification, the proportion of young people achieving an intermediate secondary school leaving certificate is lower than that of nonmigrants for all four regional origin groups differentiated. Although the differences between young people from and not from a migrant background diminish significantly as generation status rises, considerable variances frequently continue to exist in the 2 nd generation. This is particularly true of young people from a Turkish or Arab background, although it also applies to those who are of southern European origin. By way of contrast, young people from an eastern European background (including the former Soviet Union) only perform worse in the 1st generation than young people with no migrant background. By the time we reach the 3rd generation, this group is even at an advantage compared to non-migrants. Their school success is in line with the classical assimilation model.

What could be the reasons for these differences in school education success between the various origin groups? If we consider the individual migrant groups from eastern Europe, account needs to be taken of the fact that these are frequently "late resettler" families, i.e. persons of German descent. This may have made it less difficult for the young people in question to acquire a very good knowledge of German. We may also assume that the parents of these young people enjoyed a higher social status in their country of origin than in Germany in some cases and that this has been reflected in higher educational aspirations for their children. Immigrants of southern European and Turkish origin on the other hand, who were originally recruited to fill "guest worker" positions in unskilled industrial workplaces and usually came from poorly developed rural regions in their home countries, were more likely to have had a lower educational status than immigrants from eastern Europe. To this extent, it is also more likely that they children grew up in a less favourable educational environment.

The German system of dual vocational education and training and dual training in particular are largely unknown in most of the countries of origin of the young people from a migrant background. For this reason, the value of a vocational qualification on the German labour market is frequently not correctly assessed. The result of this is that interest of young migrants in dual vocational education and training is often less marked, especially in the case of young people of Turkish or Arab origin.

In Germany, progression to company-based training depends heavily on the general school qualification achieved. It is therefore particularly conspicuous that migrants still have significantly poorer chances than young people not from a migrant background of making a successful transition in this regard, even if we control for school qualification and other factors. Although chances improve as generation status rises, disadvantage of opportunity is still discernible in the 3 rd generation in some cases. What could be the reason for the lower chances of progression for young people from a migrant background, even if we control for other cause variables? It may be the case that school qualifications achieved do not reflect the performance differences that exist between the young people in overall terms. Poorer lan- 
guage competences on the part of young people from a migrant background could possibly be exerting an effect, including on those who grew up in Germany and attended a German school.

Whereas upwards-directed integration with regard to acquisition of general school qualifications can be observed as early as in the 2nd generation for migrants of eastern European origin at least, this does not apply with regard to transition to company-based training. In the 2nd generation, all origin groups display less favourable results than non-migrants, even if we control for school qualification achieved. The particularly negative results for young people from a Turkish or Arab background should be highlighted in this regard. Discrimination could also be a possible explanation for the considerably worse chances of progression exhibited by young people of Turkish or Arab origin. Much indicates that for this origin group there are particular reservations on the part of companies. This especially applies in the case of young men. Young male migrants from a Turkish background often report about experiences of discrimination (Skrobanek, 2007). One possible factor here could be the fact that the habitual disposition of young males from Turkish-Arab background differs more strongly from that of young people not from migrant background than is the case for young men from other migrant groups (El-Mafaalani \& Toprak, 2011).

If we make a comparison with the educational outcomes for migrants in traditional immigration countries such as Canada and the USA, which are better in some cases, it is noticeable that none of the four origin groups of migrants formed for Germany performs better in the educational system than non-migrants. We believe that the reason for this is that immigration to Germany has taken place in a less systematically planned way compared to other immigration countries and has also occurred without any high requirements with regard to the qualification of immigrants. Particular emphasis should be placed on the fact that the disadvantage suffered by migrants in the German school system and when accessing vocational education and training is frequently also continued into the next generation. Any comparison between different migration generations needs to be qualified by pointing out that this is a cross-sectional study rather than a longitudinal consideration. The individual generations of individual origin groups could also be composed differently because of varying historical and one-off immigration constellations. As already mentioned, for example, many of the Turkish "guest workers" who were essentially recruited to work in German industry in the 1960s and 1970s came from rural and structurally weak regions of Turkey and often displayed a low educational status. This may have been entirely different for later generations of immigrants from Turkey and the Arab region.

The results of our analyses signalise a clear need for action on the part of German policy makers and German society to reduce the educational disadvantages suffered by young migrants and to develop better support and integration measures. Young migrants should above all get better information of the German system of vocational education and training and 
the importance of recognized qualifications for the labour market in Germany. Integration is rarely achieved in the short term. It is a long-term task which frequently extends over several generations.

\section{References}

Alba, R. D., \& Nee, V. (2003). Remaking the mainstream: Assimilation and contemporary immigration. Cambridge, MA: Harvard University Press.

Algan, Y., Dustmann, C., Glitz, A., \& Manning, A. (2009). The Economic Situation of First-and Second-Generation Immigrants in France, Germany and the United Kingdom. London: Centre for Economic Performance, London School of Economics and Political Science.

Azzolini, D., \& Barone, C. (2013). Do They Progress or Do They Lag Behind? Educational Attainment of Immigrants' Children in Italy: The Role Played by Generational Status, Country of Origin and Social Class. Research in Social Stratification and Mobility, 31, 82-96. doi: 10.1016/j. rssm.2012.11.002

Becker, R. (2011). Integration von Migranten durch Bildung und Ausbildung - theoretische Erklärungen und empirische Befunde [Integration of migrants via education and training - theoretical explanations and empirical findings]. In R. Becker (Ed.), Integration durch Bildung: Bildungserwerb von jungen Migranten in Deutschland [Integration through education. The acquisition of education by young migrants in Germany] (pp. 11-36). Wiesbaden: VS Verlag.

Beicht, U., \& Walden, G. (2014). Chancennachteile von Jugendlichen aus Migrationsfamilien beim Übergang in berufliche Ausbildung. Welche Rolle spielt die soziale Herkunft? [Disadvantages of opportunity for young people from migrant families at the transition to vocational training. What role is played by social origin?]. Zeitschrift für Berufs- und Wirtschaftspädagogik [Journal of Vocational and Business Education], 110(2), 188-215.

Beicht, U., \& Walden, G. (2015a). How socially selective is the German system of initial vocational education and training? Transitions into initial vocational training and the influence of social background. Journal of Vocational Education \& Training, 67(2), 235-255, doi:10.1080/13636820. 2014.983955

Beicht, U., \& Walden, G. (2015b). Unterschiedliche Berufsinteressen als Einflussfaktor für die Einmündungschancen in betriebliche Ausbildung? Ein Vergleich zwischen männlichen und weiblichen Jugendlichen mit und ohne Migrationshintergrund [Different occupational interests as an influencing factor for chances of progression to company-based training. A comparison of young males and females from and not from a migrant background]. Journal for Labour Market Research, 48(4), 325-346, doi:10.1007/s12651-015-0193-6

Beicht, U., \& Walden, G. (2017a). Generationeneffekte beim Übergang von Schulabgängern mit Migrationshintergrund in betriebliche Ausbildung [Generational effects when school leavers from a migrant background make the transition into company-based education and training]. Zeitschrift für Berufs- und Wirtschaftspädagogik [Journal of Vocational and Business Education], 113(3), 428-460.

Beicht, U., \& Walden, G. (2017b). Transitions of young migrants to initial vocational education and training in Germany: the significance of social origin and gender. Journal of Vocational Education \& Training, 69(3 (VET, Race and Ethnicity)), 424-449, doi:10.1080/13636820.2016.1275032 
Blossfeld, H.-P., Roßbach, H.-G., \& Maurice, J. v. (2011). Education as a Lifelong Process - The German National Educational Panel Study (NEPS). Zeitschrift für Erziehungswissenschaft [Journal of Educational Science], Special Issue 14.

Boudon, R. (1974). Education, Opportunity and Social Inequality. New York: John Wiley \& Sons.

Brown, S. K., \& Bean, F. D. (2006). Assimilation Models, Old and New: Explaining a Long-Term Process. Migration Information Source. The Online Journal of the Migration Policy Institute. Retrieved from http://www.migrationpolicy.org/article/assimilation-models-old-and-new-explaininglong-term-process

Chadderton, C., \& Wischmann, A. (2014). Racialised norms in apprenticeship systems in England and Germany. Journal of Vocational Education \& Training, 66(3), 330-347. doi: $10.1080 / 13636820.2014 .917693$

Chiswick, B. R. (1988). Differences in Education and Earnings Across Racial and Ethnic Groups: Tastes, Discrimination, and Investments in Child Quality. The Quarterly Journal of Economics, 103(3), 571-597.

Chiswick, B. R., \& Deb-Burman, N. (2003). Educational Attainment: Analysis by Immigrant Generation. Bonn: IZA.

Chiswick, B. R., \& Miller, P. W. (2009). Earnings and Occupational Attainment among Immigrants. Industrial Relations: A Journal of Economy and Society 48(3), 454-465. doi: 10.1111/j.1468232X.2009.00568.x

Diehl, C., \& Granato, N. (2018). Chapter 3. Germany. Intergenerational inequalities in the education system and the labour market for native-born children of immigrants from Turkey and the former Yugoslavia. In OECD (Ed.), Catching Up? Country Studies on intergenerational Mobility and Children of Immigrants (pp. 71-89). Paris: OECD Publishing.

Ditton, H. (2008). Der Beitrag von Schule und Lehrern zur Reproduktion von Bildungsungleichheit [The contribution of school and teachers to the reproduction of educational inequality]. In R. Becker, \& W. Lauterbach (Eds.), Bildung als Privileg. Erklärungen und Befunde zu den Ursachen der Bildungsungleichheit (3. Auflage) [Education as a privilege. Explanations and findings on the causes of educational inequality (3rd edition)] (pp. 247-275). Wiesbaden: VS Verlag.

Domingues Dos Santos, M., \& Wolff, F-C. (2011). Human capital background and the educational attainment of second-generation immigrants in France. Economics of Education Review, 30(5), 1085-1096. doi: 10.1016/j.econedurev.2011.05.012

Dustmann, C., Frattini, T., \& Lanzara, G. (2012). Educational achievement of second-generation immigrants. An international comparison. Economic Policy, 27(69), 143-185. doi: 10.1111/j.14680327.2011.00275.x

Eberhard, V. (2012). Der Übergang von der Schule in die Berufsausbildung. Ein ressourcentheoretisches Modell der Übergangschancen von Ausbildungsstellenbewerbern [Transition from school to vocational education and training. A theoretical resources-based model to explain the transition chances of training place applicants]. Bielefeld: W. Bertelsmann.

El-Mafaalani, A., \& Toprak, A. (2011). Muslimische Kinder und Jugendliche in Deutschland [Muslim children and young people in Germany]. Sankt Augustin, Berlin: Konrad Adenauer Stiftung.

Esser, H. (2006). Migration, Sprache und Integration. AKI-Forschungsbilanz 4 [Migration, language and integration. AKI Research Summary 4]. Berlin: Office for Intercultural Conflicts and Societal Integration (AKI) at the Social Science Research Centre Berlin (WZB). 
Feliciano, C. (2005). Does Selective Migration Matter? Explaining Ethnic Disparities in Educational Attainment among Immigrants' Children. International Migration Review, 39(4), 841-871. doi: 10.1111/j.1747-7379.2005.tb00291.x

Feliciano, C. (2006). Beyond the Family. The Influence of Premigration Group Status on the Educational Expectations of Immigrants' Children. Sociology of Education, 79(4), 281-303. doi: 10.1177/003804070607900401

Glazer, N., \& Moynihan, D. P. (1963). Beyond the Melting Pot: The Negroes, Puerto Ricans, Jews, Italians, and Irish of New York City. Cambridge, MA: MIT Press.

Gordon, M. (1964). Assimilation in American Life. New York: Oxford University Press.

Heath, A. F., Rothon, C., \& Kilpi, E. (2008). The Second Generation in Western Europe: Education, Unemployment, and Occupational Attainment. Annual Review of Sociology, 34, 211-235. doi: 10.1146/annurev.soc.34.040507.134728

Hunkler, C. (2014). Ethnische Ungleichheit beim Zugang zu Ausbildungsplätzen im dualen System [Ethnic inequality in access to training places in the dual system]. Wiesbaden: Springer VS.

Ichou, M. (2014). Who They Were There. Immigrants' Educational Selectivity and Their Childrens Educational Attainment. European Sociological Review, 30(6), 750-765. doi: 10.1093/esr/jcu071

Ichou, M., \& Vallet, L.-A. (2013). Academic Achievement, Tracking Decisions, and Their Relative Contribution to Educational Inequalities: Change over Four Decades in France. In M. Jackson (Ed.), Determined to succeed? Performance versus choice in educational attainment (pp. 116-148). Stanford Calif.: Stanford Univ. Press (Studies in social inequality).

Jackson, M., Jonsson, J. O., \& Rudolphi, F. (2012). Ethnic Inequality in Choice-Driven Education Systems. A Longitudinal Study of Performance and Choice in England and Sweden. Sociology of Education 85(2), 158-178. doi: 10.1177/0038040711427311

Kristen, C., Edele, A., Kalter, F., Kogan, I., Schulz, B., Stanat, P., \& Will, G. (2011). 8 The education of migrants and their children across the life course. Zeitschrift für Erziehungswissenschaft, 14(2), 121-137. doi: 10.1007/s11618-011-0194-3

OECD. (2018a). Migration Policy Debates: How does having immigrant parents affects the outcomes of children in Europe. Paris: OECD.

OECD. (2018b). The Resilience of Students with an Immigrant Background. Factors that Shape WellBeing. Paris: OECD.

Olczyk, M., Will, G., \& Kristen, C. (2016). Immigrants in the NEPS: Identifying generation status and group of origin. NEPS Survey Paper No. 4. Bamberg: Leibniz Institute for Educational Trajectories.

Phalet, K., Deboosere, P., \& Bastiaenssen, V. (2007). Old and new inequalities in educational attainment. Ethnicities, 7(3), 390-415. doi: 10.1177/1468796807080235.

Picot, G., \& Hou, F. (2011). Preparing for success in Canada and the United States. The determinants of educational attainment among the children of immigrants. Ottawa.

Portes, A., \& Zhou, M. (1993). The New Second Generation: Segmented Assimilation and Its Variants. Annals of the American Academy of Political and Social Science, Vol. 530, Interminority Affairs in the U.S.: Pluralism at the Crossroads, 74-96.

Ryabov, I. (2009). The Role of Peer Social Capital in Educational Assimilation of Immigrant Youths. Sociological Inquiry, 79(4), 453-480. doi: 10.1111/j.1475-682X.2009.00300.x

Segeritz, M., Walter, O., \& Stanat, P. (2010). Muster des schulischen Erfolgs von jugendlichen Migranten in Deutschland: Evidenz für segmentierte Assimilation? [Patterns of school success of young migrants in Germany - evidence of segmented assimilation?]. Kölner Zeitschrift für Soziologie 
und Sozialpsychologie [Cologne Journal of Sociology and Social Psychology], 62(1), 113-138, doi:10.1007/s11577-010-0094-1

Skrobanek, J. (2007). Wahrgenommene Diskriminierung und (Re)Ethnisierung bei Jugendlichen mit türkischem Migrationshintergrund und jungen Aussiedlern [Perceived discrimination and (re) ethnicisation of young people from a Turkish migrant background and young resettlers]. Zeitschrift für Soziologie der Erziehung und Sozialisation (ZSE) [Journal of Sociology of Education and Socialisation], 27(3), 265-284.

Spence, M. (1973). Job market signaling. The quarterly journal of economics, 87(3), 355-374.

Thurow, L. C. (1979). A job competition model. In M. J. Piore (Ed.), Unemployment and inflation (pp. 17-32). New York: M.E. Sharpe.

Tjaden, J. D. (2013). Migrants and Vocational Education in the European Union: A review of evidence on access and dropout. SIRIUS: European Policy Network on the education of children and young people with a migrant background.

\section{Biographical notes}

Ursula Beicht is an academic researcher in the 'Sociology and Economics of Vocational Education and Training' Department at the Federal Institute for Vocational Education and Training, Bonn. Her main research topics have been transitions from school to training and work, participation of young migrants in general education and vocational education and training costs and benefits of vocational education and training.

Dr. Günter Walden is a retired director of the Federal Institute for Vocational Education and Training, Bonn, and a former Head of the 'Sociology and Economics of Vocational Education and Training' Department. His main research topics have been transitions from school to training and work, participation of young migrants in general education and vocational education and training, training behaviour of companies, costs and benefits of vocational education and training. 